\title{
C-23 FACIES AND PROCESSES OF TURBIDITE SYSTEMS
}

EMILIANO MUTTI and ROBERTO TINTERRI

Parma University, Dipartimento di Scienze della Terra,

Parco Area delle Scienze 157/A, 43100 Parma, italy

Over the past two decades marine geological investigations, outcrop studies, laboratory experiments and numerical modelling, and, particularly, a wealth of seismic, well-log and core data derived from extensive exploration for hydrocarbons carried out in many offshore basins worldwide, have provided an increasing body of evidence indicating the very complex and still poorly understood nature of many deep-water sandstone facies.

These sandstones, first interpreted as the deposit of turbidity currents and referred to as "resedimented graded sandstone beds" by Kuenen and Migliorini (1950), were later termed "turbidites" by Kuenen (1957). Fifty years after these breakthrough papers, turbidity currents appear to be more complex than originally thought, forming a spectrum of genetically linked sediment gravity flows that range from cohesive and very dense debris flows to dilute turbulent flows (Middleton and Hampton, 1973; Lowe, 1982). It is also clear that the deposits of these flows show a great variety of textures, bedding geometry and internal depositional divisions, i.e. a very broad spectrum of facies types (e.g., Mutti et al., 1999). The reservoir characteristics of these sediments are strictly related to their facies characteristics which, in turn, depend mainly upon the mechanisms of sediment transport and deposition.

In this paper we discuss turbidite facies and related processes as derived from extensive outcrop studies of basin-fills exposed in thrust-fold belts. Particularly in their axial portions, where the topographic control on sedimentation in negligible, facies tracts established through careful stratigraphic correlations provide a considerable insight into turbidite sedimentations and therefore predictive models that can be used also in other types of geologic settings.

Most turbidity currents can be viewed as bipartite density currents, each consisting of a dense basal flow, primarily driven by inertial forces under conditions of excess-pore pressure and carrying relatively coarse-grained sediment, and an upper fully turbulent flow mainly loaded with fine sand and mud (Fig. 1).

We interpret turbidite facies associations containing a substantial proportion of conglomerate, pebbly-sandstone and massive-sandstone facies as the deposit of submarine granular flows directly fed by heavily-loaded hyperpycnal flows emanating from coarse-grained delta systems.

During the downslope motion of the basal granular layer, coarser grains outdistance finer grains (Fig. 1); as a result, coarser grains collect at the head of the flow giving way to a negative horizontal grain-size gradient in a downcurrent direction (Sanders, 1965; Mutti et al., 1999, with references therein). When the frontal part of the flow freezes because of internal friction, finer grains which were being transported behind overtake and step over the newly formed deposit and keep moving downcurrent producing another horizontal grain-size gradient within the flow. The process will continue until the basal 
dense layer is entirely deposited through a series of sedimentation waves each characterized by progressively finer-grained sediment in a downcurrent direction ( $c f$. Lowe, 1982; Mutti, 1992). Successive and progresssively finer-

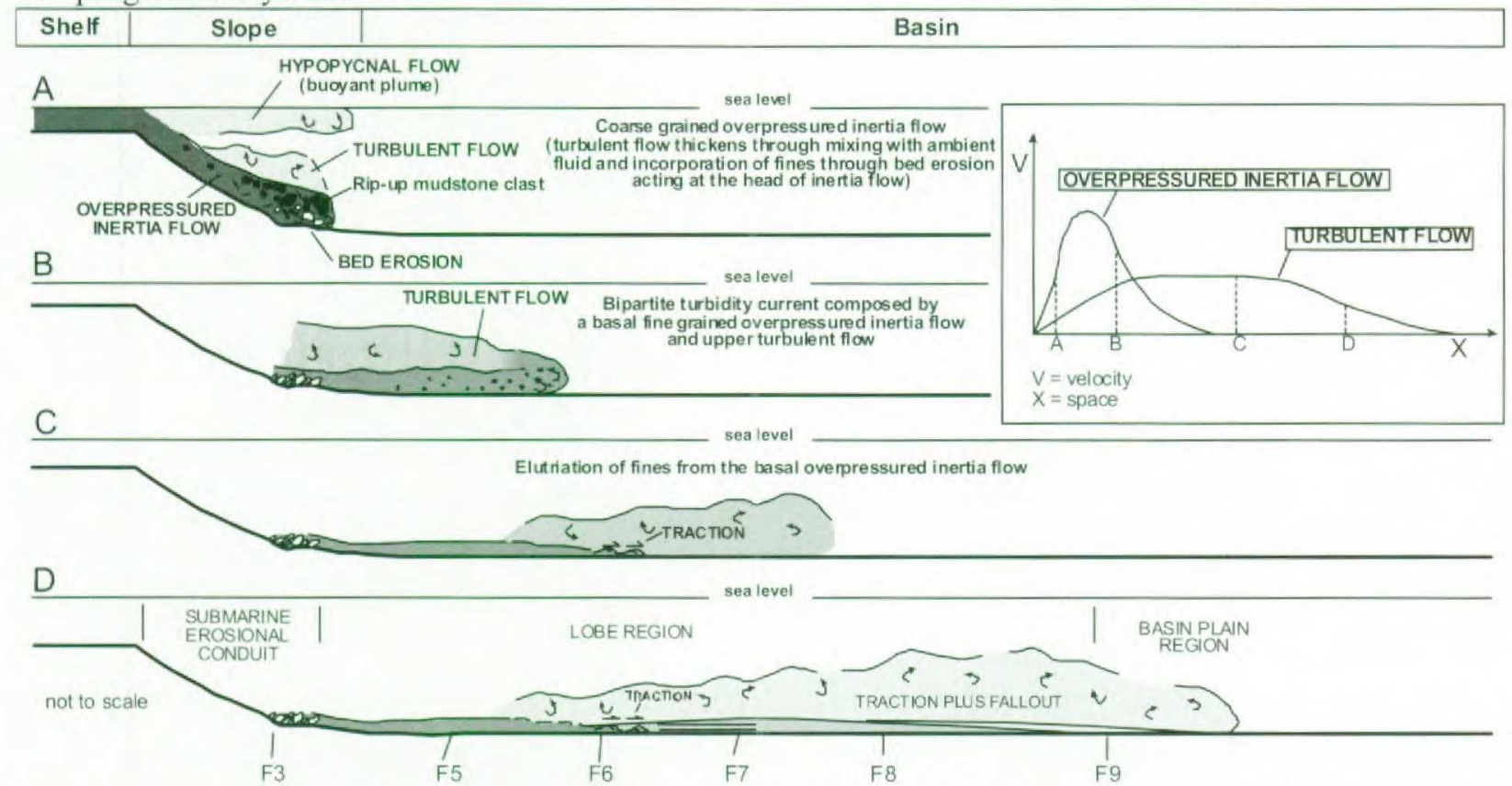

Fig. 1 - Main erosional and depositional processes operating in a turbidite system dominated by highly-efficient flows (sligthly modified from Mutti et al., 1999).

grained sedimentation waves may produce substantial sediment bypass along the path of each flow; this process is recorded by distinct breaks in grain size within the deposit. The upper turbulent flow will eventually outdistance the deposit of the basal granular layer and carry its suspended sediment farther basinward. Briefly, the general process that can be envisaged is one through which the granular layer flows due to inertia forces and progressively increasing shear stress imparted from the overlying turbulent flow, whereas the latter moves as an "ideal" turbidity current in which the excess density is due to its sediment load kept in suspension by turbulence. Based on facies tracts reconstructed from the axial zone of many ancient exposed basin fills, the scheme of Fig. 2 show that the basinward evolution of a bipartite turbidity current is expressed by consistent relationships between facies types and inferred processes, providing a useful predictive model for the analysis of turbidite systems.

Departures from this model are commonly observed wherever flow efficiency - i.e, the ability of the flow to carry its sediment load in a basinward direction and fully segregate it longitudinally and laterally into relatively well-sorted facies types - is lowered by local factors. The latter include, among others: (1) gradient and length of the slope along which turbidity currents are accelerated, (2) topography of the depositional zones, (3) volume and textural composition of the parental flow, and (4) flow duration (sustained vs surge-type flows). Poorly efficient flows generally produce poorly-sorted facies types, thus lowering the reservoir quality of the deposit.

Detailed facies analysis of a significant number of turbidite basin-fills from thrust-fold belts shows that relatively long-lived turbidite systems generally consist of three main elements (Fig. 1):

(1) a conduit along which turbidity currents, essentially represented by coarse grained flows driven by inertial forces under conditions of excess pore pressure, are accelerated and become highly erosive; 
ロロロロロロロロロロロロ ロ

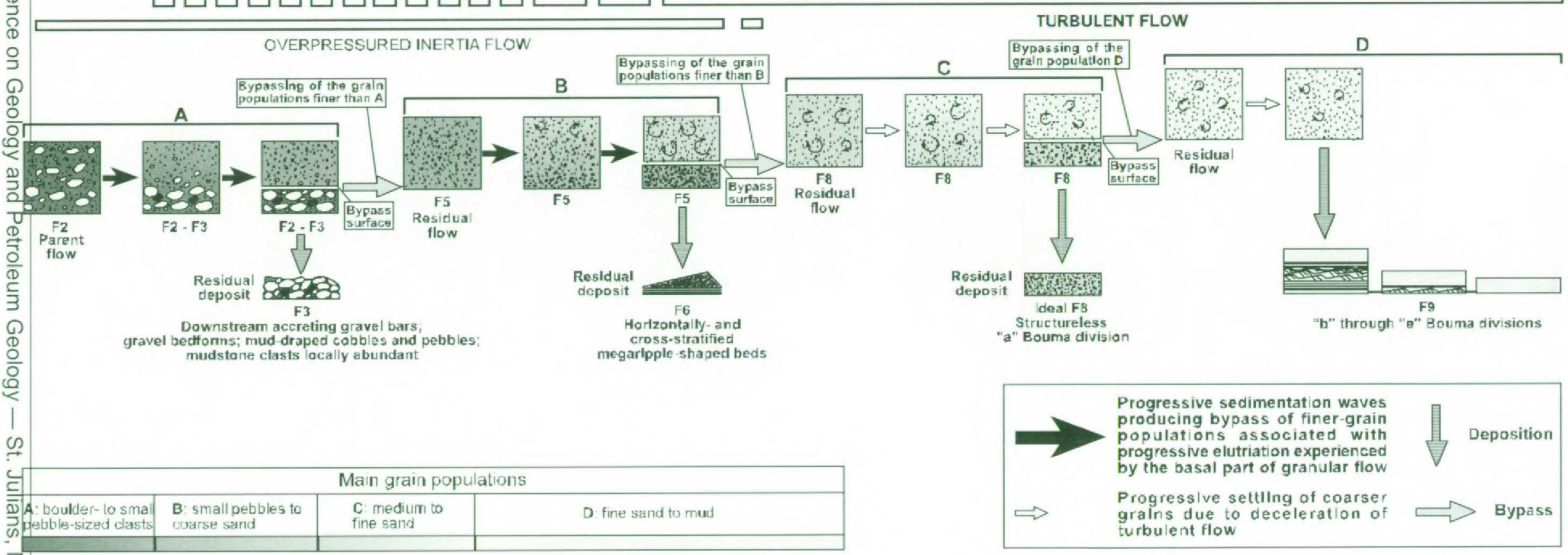


(2) a basin-proximal depositional zone where the basal dense flows are forced to decelerate due to increasing grain-to-grain and bed friction, and

(3) a basin-distal depositional zone characterized by the deposition of the upper turbulent flows due to their deceleration in space and time. Due to structural basin confinement, most large-volume turbidity currents undergo ponding in these distal regions.

These three elements are expressed by very distinctive and mappable erosional and depositional features. Zone 1 is typically recorded by large-scale erosional features which may contain axial coarsegrained facies left behind by bypassing flows; zone 2 is expressed by relatively coarse-grained sandstones (sandstone lobes of Mutti and Ricci Lucchi, 1972), most commonly occurring as thick and mostly structureless beds which are either amalgamated or separated by thin to very thin mudstone layers; and zone 3 is characteristically recorded by fine-grained and thoroughly current-laminated sandstones interbedded with mudstones. In the absence of pronounced submarine relief, zones 2 and 3 are expressed by sandstone beds characterized by a remarkable lateral continuity along the axis of the basin.

Although size, geometry and facies characteristics of the three above elements may considerably vary. from one system to another as a function of the locally controlling factors, erosional conduits, sandstone lobes and basin-plain deposits form the basic plan-view architecture of a turbidite system. Within each system considered, the relative position and the extent of each three zones vary through time as a result of cyclic changes in the volume of turbidity currents, which are likely to be related to similarly cyclic climate variations in the source zone (see Mutti et al., 1999 for more details).

\section{REFERENCES:}

Kuenen Ph.H. (1957) - Sole markings of graded graywacke beds. Journ. Geol., v. 65, pp. 231-258.

Kuenen Ph.H. and Migliorini C.I. (1950) - Turbidity currents as a cause of graded bedding. Journ. Geol., v. 58, pp. 91-127.

Lowe D.R. (1982) - Sediment gravity flows: II. Depositional models with special reference to the deposits of high-density turbidity currents. Journ. Sed. Petr., v. 52 (1), pp. 279-297.

Middleton G.V. and Hampton M.A. (1973) - Sediment gravity flow: mechanics of flow and deposition. In Middleton G.V. and Bouma A.H. (Eds.), Turbidites and deep-water sedimentation; Pacific section, S.E.P.M. Short Course Notes ${ }^{\circ} 1$, pp. 1-38.

Mutti E. (1992) - Turbidite Sandstones. AGIP - Istituto di Geologia, Università di Parma, 275 p.

Mutti E. and Ricci Lucchi F. (1972) - Le torbiditi dell' Appennino Settentrionale: introduzione all'analisi di facies. Mem. Soc. Geol. It., v. 11, pp. 161-199.

Mutti, E., Tinterri, R., Remacha, E., Mavilla, N., Angella, S. and Fava, L. (1999) : An introduction to the analysis of ancient turbidite basins from an outcrop perspective. A.A.P.G., Continuing Education Course Note Series, $\mathrm{n}^{\circ} 39,61 \mathrm{p}$.

Sanders J.E. (1965) - Primary sedimentary structures formed by turbidity currents and related resedimentation mechanisms. In Middleton G.V. (Ed.), Primary sedimentary structures and their hydrodynamic interpretation, S.E.P.M. Spec. Publ., n 12, pp. 192-219. 